\title{
Heat-related deaths
}

\author{
Roger W. Byard
}

Accepted: 31 January 2013/Published online: 16 March 2013

(C) Springer Science+Business Media New York 2013

While vigorous debate continues concerning the nature and/or extent of global warming, it has been suggested that the number, length, and intensity of heat waves experienced globally is increasing [1, 2]. Certainly, forensic pathologists are continually encountering cases where deaths may have either been caused by, or associated with, high environmental temperatures, and in many parts of the world there does appear to have been an increase in numbers of heat-related deaths [3, 4]. In January-February 2009, summer temperatures in Adelaide, the capital of South Australia, reached record levels, with 8 days having maximum temperatures above $40{ }^{\circ} \mathrm{C}$, including the hottest day in 70 years with a temperature of $45.7^{\circ} \mathrm{C}$ [5]. The results of this heat wave included a marked increase in deaths, particularly of elderly individuals with underlying cardiovascular disease. Other studies have shown that children are also at risk [6]. Given the unprecedented numbers of victims in the South Australian heat wave, a refrigerated container had to be hired and installed next to the state mortuary to deal with the increased storage requirements, something that had never previously been required. These events create a number of problems for forensic pathologists ranging from simple logistical issues of having to deal with markedly increased numbers of cases, to diagnostic issues around determining causes of death.

Making a diagnosis of a heat-related death may be quite difficult at autopsy as commonly found features such as skin slippage, pleural petechiae, and pulmonary and

\section{R. W. Byard $(\square)$}

Discipline of Anatomy and Pathology, Level 3 Medical School North Building, The University of Adelaide, Frome Road, Adelaide, SA 5005, Australia

e-mail: roger.byard@sa.gov.au cerebral edema are entirely nonspecific [7]. Only very rarely will a core temperature of a body proximate to the time of death be available, and heat often accelerates decomposition which further complicates post mortem assessment [8]. Occasionally there may be convincing evidence of prolonged exposure to high temperatures, for example in a sweat lodge [9], or a history of coma or muscle spasm resulting from a significant elevation of core temperature. Dehydration may be an associated feature at autopsy $[9,10]$. While survival for some time with a high temperature may be associated with the development of acute pancreatitis, centrilobular necrosis of the liver, cerebral neuronal degeneration, acute tubular necrosis of the kidneys, and rhabdomyolysis [7], the latter may also suggest drug exposure [11]. The association of hyperthermia with drugs such as cocaine and the ring derivate amphetamines such methylenedioxymethamphetamine, MDMA or "ecstasy," and paramethoxyamphetamine or PMA is well recognized and necessitates full toxicological evaluation of each case $[12,13]$. In addition, certain prescription medications such as tricyclic antidepressants and antihistamines with anticholinergic effects, certain antiparkinsonian drugs, and neuroleptic drugs such as some of the major tranquilizers, may all predispose to hyperthermia [14]. As periods of high environmental temperatures may be associated in various parts of the world, such as Australia, with serious brush/bushfire outbreaks, the autopsy load may also be added to by fire deaths [15]. For example, in the Australian state of Victoria in February 2009 the hottest day to date of $46.4{ }^{\circ} \mathrm{C}$ was recorded, with heat-related deaths occurring in of over 400 people around this time, and a further 173 deaths occurring associated directly with the bushfires [16].

To standardize the approach to, and the diagnosis of, hyperthermic deaths certain criteria have been proposed 
which include a history of the decedent being alive at the time of the high temperatures, decomposition, a core temperature of $\geq 40.6^{\circ} \mathrm{C}\left(105^{\circ} \mathrm{F}\right)$, and a high environmental temperature at the death scene $\left(>37.8^{\circ} \mathrm{C}\right)\left(100{ }^{\circ} \mathrm{F}\right)$ [17]. As a number of these criteria may be missing it has been suggested that "hyperthermia" or "heat stroke" should only be used if it is known that the body temperature at the time of collapse was $\geq 40.6{ }^{\circ} \mathrm{C}\left(105^{\circ} \mathrm{F}\right)$. It is still possible, however, to use these terms with lower body temperatures if the body has been cooled, if there was a history of altered mental status, or if liver and muscle enzymes were elevated indicating heat exposure [17, 18]. The National Association of Medical Examiners in the United States has further suggested that "heat-related death" is a useful term for cases where high temperatures may have either caused death or significantly contributed to it, but the body temperature at the time of collapse or death cannot be determined, and no other cause of death is present [19].

Given the possibility that an increasing number of heatrelated deaths may be coming through forensic facilities it is important that high-risk periods can be identified so that morgues can prepare for the increased workload associated with these types of deaths. For this reason a mathematical formulation termed the Excess Heat Factor has recently been derived based on long-term local metereological data to allow a more accurate indication of the severity of a heat event to be determined, rather than merely relying on sequentially recording maximum daily temperatures [3]. This calculation can provide a way of scoring environmental temperature load and thus enable prediction of the likelihood of a significant increase in the number of heat related deaths. It can also be used in clinical practice to predict increases in heat related morbidity [3]. The two major components of successfully dealing with major clusters of deaths arising from heat waves remain forewarning and disaster victim management preparedness [20].

\section{References}

1. O'Neill MS, Carter R, Kish JK, Gronlund CJ, White-Newsome JL, Manarolla X, Zanobetti A, Schwartz JD. Preventing heatrelated morbidity and mortality: new approaches in a changing climate. Maturitas. 2009;64:98-103.

2. Wassel JJ. Public health preparedness for the impact of global warming on human health. Am J Disaster Med. 2009;4:217-25.
3. Bustinza R, Lebel G, Gosselin P, Bélanger D, Chebana F. Health impacts of the July 2010 heat wave in Québec, Canada. BMC Public Heath. doi:10.1186/1471-2458-13-56.

4. Son JY, Lee JT, Anderson GB, Bell ML. The impact of heat waves on mortality in seven major cities in Korea. Environ Health Perspect. 2012;120:566-71.

5. Langlois NEI, Herbst J, Mason K, Nairn J, Byard RW. Use of excess heat factor (EHF) to predict the risk of heat related deaths. J Forensic Leg Med. doi:10.1016/j.jflm.2012.12.005.

6. Krous HF, Nadeau JM, Fukumoto RI, Blackbourne BD, Byard RW. Environmental hyperthermic infant and early childhood death: circumstances, pathologic changes, and manner of death. Am J Forensic Med Pathol. 2001;22:374-82.

7. Green H, Gilbert J, James R, Byard RW. An analysis of factors contributing to a series of deaths due to exposure to high environmental temperatures. Am J Forensic Med Pathol. 2001;22:196-9.

8. Zhou C, Byard RW. Factors and processes causing accelerated decomposition in human cadavers. An overview. J Forensic Leg Med. 2011;18:6-9.

9. Byard RW, Riches KJ. Dehydration and heat-related death. Sweat lodge syndrome. Am J Forensic Med Pathol. 2005;26:236-9.

10. Whitehead FJ, Couper RTL, Moore L, Bourne AJ, Byard RW. Dehydration deaths in infants and young children. Am J Forensic Med Pathol. 1996;17:73-8.

11. Byard RW, Summersides G, Thompson A. Muscle pallor-a macroscopic marker of cocaine-induced rhabdomyolysis. Forensic Sci Med Pathol. 2011;7:364-6.

12. Milroy CM. "Ecstasy" associated deaths: what is a fatal concentration? Analysis of a case series. Forensic Sci Med Pathol. 2011;7:248-52.

13. Byard RW, Rodgers NG, James RA, Kostakis C, Camilleri AM. Death and paramethoxyamphetamine-an evolving problem? (Letter). Med J Aust. 2002;176:496.

14. Heat-related illnesses and deaths. Missouri, 1998, and United States, 1979-1996. MMWR. 1999;48:469-73.

15. Byard RW, Gilbert JD, Kostakis C, Heath K. Circumstances of death and diagnostic difficulties in brushfire fatalities. J Forensic Sci. 2012;57:969-72.

16. Cordner SM, Woodford N, Bassed R. Forensic aspects of the 2009 Victorian bushfire disaster. Forensic Sci Int. 2011;205:2-7.

17. Whitman S, Good G, Donoghue ER, Benbow N, Shou W, Mou S. Mortality in Chicago attributed to the July 1995 heat wave. Am L Pub Health. 1997;87:1515-8.

18. Shen T, Howe HL, Alo C, Moolenaar RL. Toward a broader definition of heat-related death: comparison of mortality estimates from medical examiners' classification with those from total death differentials during the July 1995 heat wave in Chicago, Illinois. Am J Forensic Med Pathol. 1998;19:113-8.

19. Donoghue ER, Graham MA, Jentzen JM, Lifschultz BD, Luke JL, Mirchandani HG. Criteria for the diagnosis of heat-related deaths: National Association of Medical Examiners: position paper. Am J Forensic Med Pathol. 1997;18:11-4.

20. Winskog C, Tsokos M, Byard RW. The progression from disaster victim identification (DVI) to disaster victim management (DVM) - a necessary evolution. Forensic Sci Med Pathol. 2012;8:81-3. 